Ks. Andrzej Maryniarczyk

Katolicki Uniwersytet Lubelski Jana Pawła II

\title{
ANTROPOLOGICZNO-METAFIZYCZNE PODSTAWY ADEKWATNEJ TEORII WYCHOWANIA W UJECIU TWÓRCÓW FiLOZOFICZNEJ SZKOŁY LUBELSKIEJ
}

\author{
The anthropologico-metaphysical basis of an adequate theory of education in terms of \\ creators of Lublin School of Philosophy
}

\begin{abstract}
S u m m a ry: The phrase in the title of the article "anthropologico-metaphysical basis " promises to reference, not so much to a philosophical system that would become the basis for a theory of education, but rather to a certain research attitude that stands out due to its realism. This type of approach boils down to the "art of reading" that which really exists: real people and real things, and discovering in them the necessary causes of their existence, actions and common properties. The article argues that a correct reading of the truth about man, of who he is, of what the ultimate source of his existence is, and of what the ultimate purpose of his life is, constitutes an indispensable condition for the formation of an adequate theory of education. Within the framework of philosophical knowledge, we discover that man is a person, that is, an individual subject, who is the source of free and rational actions due to his specific nature and the fact that he is an entity living in the perspective of the Absolute (God), which indicates a reading of the ultimate truth about the existence of the world and man. This type of knowledge provides pedagogy with a realistic metaphysics and philosophical anthropology that was formulated and developed within the framework of the Lublin School of Philosophy.
\end{abstract}

Keyw ord s: philosophical anthropology, metaphysics, person, theory of education, pedagogy

Tytuł artykułu, a mianowicie: Antropologiczno-metafizyczne podstawy adekwatnej teorii wychowania w ujęciu twórców Filozoficznej Szkoty Lubelskiej wymaga na początku pewnego wyjaśnienia. Po pierwsze, wyrażenie „metafizyczno-antropologiczne podstawy" zapowiada nie tyle jakiś system filozoficzny, który stałby u podstaw teorii wychowania, co pewną postawę badawczą, która wyróżnia się realizmem, to znaczy, 
że ma za przedmiot dociekań świat realny ${ }^{1}$. Tego typu postawa badawcza sprowadza się do „sztuki czytania” realnie istniejących bytów: osób i rzeczy oraz odkrywania w nich koniecznych przyczyn istnienia i działania oraz powszechnych właściwości. Zwykle mówimy o czytaniu tekstów, tymczasem okazuje się, że każda realna rzecz jest takim tekstem, który został zapisany przez jej twórcę lub Stwórcę po postacią projektu (idei). A zatem odczytanie prawdy o świecie i człowieku jest podstawą adekwatnej teorii wychowania.

Po drugie, poprawne odczytanie prawdy o człowieku, o tym, kim jest, jakie jest ostateczne źródło jego istnienia oraz ostateczny cel jego życia, stanowi nieodzowny warunek formowania adekwatnej teorii wychowania. W ramach poznania filozoficznego odkrywamy, że człowiek jest osobą, to znaczy jednostkowym podmiotem, będącym źródłem wolnego i rozumnego działania, posiadającym określoną naturę oraz jest istotą żyjącą w perspektywie Absolutu (Boga), na co wskazuje odczytanie ostatecznej prawdy o istnieniu świata i człowieka. Tego typu wiedzy dostarcza pedagogice metafizyka i antropologia filozoficzna.

Po trzecie, temat artykułu zapowiada, że przyjęty obraz świata i człowieka według twórców Lubelskiej Szkoły Filozoficznej zawsze stoi u podstaw adekwatnej teorii wychowania. Dlaczego metafizyka i antropologia? Czy nie wystarczy sama antropologia, samo rozumienie człowieka, by na nim budować adekwatną teorię wychowania? W wielu przypadkach tak się dzieje i dziś można by powiedzieć, że jest to dość powszechne przekonanie wśród teoretyków wychowania. Są jednak pewne dane historyczne, a także i empiryczne, które każą szerzej patrzeć na proces formowania obrazu człowieka, bowiem u podstaw adekwatnego rozumienia człowieka stoi właściwe rozumienie bytu.

\section{W poszukiwaniu adekwatnego obrazu człowieka}

Twórcy Fillozoficznej Szkoły Lubelskiej² zauważyli, przyglądając się dziejom filozofii, że u podstaw rozumienia człowieka stoi zawsze rozumienie bytu, czyli tego, czym są rzeczy tworzące świat realny. Jeśli tu popełni się - jak ostrzegał Arystoteles - mały błąd, to na końcu stanie się on wielki³. Jeśli więc przyjmiemy fałszywy (błędny) obraz bytu, otrzymamy też fałszywy (błędny) obraz człowieka (a także i Boga). Wystarczy tu przypomnieć, że zawirowania w rozumieniu człowieka, które przyszły wraz z ideologią

\footnotetext{
${ }^{1}$ Także wyrażenie „realizm filozoficzny Lubelskiej Szkoły Filozoficznej” należy rozumieć bardziej jako pewną postawę badawczą, którą wyróżnia przedmiot badania (świat realny), metoda i cel, niż jako system filozoficzny utożsamiany z systemem Arystotelesa czy św. Tomasza z Akwinu. Postawę bowiem realistyczną wyróżnia przede wszystkim to, iz dla realisty jedynym autorytetem, wobec którego podporządkowuje swój rozum, jest rzecz realna, realny człowiek, realny świat, zaś Arystoteles czy Tomasz z Akwinu przywoływani są o tyle, o ile pomagają naprowadzić intelekt realisty na czytanie rzeczy.

${ }^{2}$ Zob. szerzej Andrzej Maryniarczyk, Mieczysław. A. Krąpiec, „Lubelska Szkoła Filozoficzna”, w: Powszechna encyklopedia filozofii, t. 6, red. nacz. Andrzej Maryniarczyk (Lublin: PTTA 2005), 532-550

3 „Nieznaczne odchylenie od prawdy, popełnione na samym początku, rośnie do rozmiarów dziesiątków tysięcy, w miarę jak postępuje badanie”, Arystoteles, O niebie, przekł. P. Siwek, Dzieła wszystkie, t. 2 (Warszawa: PWN 1990), 271 b 8-13.
} 
gender mają swe podstawy w błędnym rozumieniu bytu. I tak na przykład: pierwsi filozofujący przyrodnicy (tak zwani philosophesantes) formowali obraz człowieka, odwołując się do paradygmatu bytu materialnego, który pojmowali jako agregat elementów. Człowiek rozumiany był jako przysłowiowy „składak”, który różni się od innych bytów tylko układem elementów oraz ich funkcją. Paradygmat ten leży u podstaw wszelkiego typu materialistycznych i mechanicystycznych koncepcji człowieka ijest wypadkową dociekań prowadzonych metodami nauk przyrodniczych, redukujących całe bogactwo duchowego życia człowieka do funkcji materii; zbudowana na takim obrazie teoria wychowania będzie bardziej przypominać teorię „tresury”.

Z kolei Platon zbudował obraz człowieka na paradygmacie idei, która odbija się w świecie materii. Idealny człowiek to sam duch (bóstwo) uwięziony w strukturze materii; ten platoński paradygmat legnie u podstaw różnych spirytystycznych i angelologicznych koncepcji człowieka oraz ujęć dualistycznych (typu kartezjańskiego). Z kolei jeśli będzie stanowił podstawę teorii wychowania, spowoduje redukcję całego wychowania do kształcenia intelektualnego.

Trzeci paradygmat, który odnajdujemy w historii, to obraz bytu organicznego, złożonego z ciała i duszy (hylemorfizm), co ujawnia się w sposób szczególny w naturze zwierzęcia; do antropologii został wprowadzony przez Arystotelesa. Człowiek to zwierzę rozumne, gr. zoon logikon, łac. animal rationale. Elementem antropotwórczym jest czynnik rozumu, który udzielany zwierzęciu od zewnątrz, czyni go zwierzęciem rozumnym, czyli człowiekiem. I choć wypracowany przez Arystotelesa obraz dał początek budowaniu adekwatnej, realistycznej wizji człowieka, to jednak stając na stanowisku, że „człowiek pochodzi z natury i powstaje podług natury”, sprawia, że paradygmat ten stanowi podstawę różnego rodzaju naturalistycznych koncepcji człowieka ${ }^{4}$, a przeniesiony do formowania teorii pedagogicznych, choć obejmuje w sobie bogactwo życia uczuciowego i moralnego człowieka, jednak pomija w nim aspekt życia duchowego i zamyka całą perspektywę życia do świata natury.

Wśród kolejnych spotykanych paradygmatów rozumienia człowieka odnajdujemy czwarty, a mianowicie paradygmat substancji, czyli podmiotu, który bytuje w sobie, jest jednostkowy, rozumny i zdolny do autonomicznego działania. Paradygmat ten stoi u podstaw rozumienia człowieka jako osoby. Jest on rezultatem dociekań metafizycznych, łączy w sobie rozumienie bytu jako substancji, ale nie sprowadza do niego rozumienia człowieka, gdyż wyróżnia go jako Osobę, a więc specyficzną substancję: jednostkową, rozumną, charakteryzującą się specyficznym dynamizmem ${ }^{5}$. Paradygmat ten przynosi przełom w rozumieniu człowieka, a także w sposobie jego poznawania i wyjaśniania. Ale i tu spotykamy się z różnymi paradygmatami przy formowaniu się rozumienia człowieka jako osoby.

\footnotetext{
${ }^{4}$ Zob. szerzej Mieczysław A. Krąpiec, „Człowiek”, w: Powszechna encyklopedia filozofii, t. 2, red. nacz. Andrzej Maryniarczyk (Lublin: PTTA 2001), 359-386.

${ }^{5}$ Pozostałe paradygmaty, z którymi spotkamy się w filozofii nowożytnej i współczesnej, odwołują się do wyróżnionej jakiejś funkcji lub właściwości, którą uznają za typowe dla człowieka. Stąd pojawiają się takie określenia człowieka jak: homo symbolicus; homo faber, homo viator, homo ridens, homo religiosus, homo electronicus itd.
} 
Pierwszym z paradygmatów należących do grupy „człowiek jako osoba” jest paradygmat chrystologiczno-trynitarny. Jego specyfiką jest postrzeganie osoby w kontekście Osób Trójcy Świętej (Bóg w trzech Osobach) o statusie bytu relacyjnego, a nie substancjalnego. Osoby Boskie odsłaniają wewnętrzne życie Boga (stwarzanie, zbawienie i uświęcanie). I choć rozumienie Osoby Boskiej Chrystusa dokonało się na bazie definicji Boecjusza (w IV wieku), to często jest ono nierozróżnialne od osoby ludzkiej. Ten paradygmat relacyjnej koncepcji osoby legł u podstaw współczesnych koncepcji, zjakimi spotykamy się na przykład $\mathrm{w}$ filozofii dialogu, procesu, a także w innych nurtach filozoficznych.

Z kolei drugi paradygmat - angelologiczny - uznaje osobę za czystą inteligencję, byt duchowy, res cogitans. Konsekwencją tego podejścia jest redukcja człowieka do „czystej świadomości”, „samoświadomej jaźni” i podobnych. Odnosząc się do dyskusji, jaka toczy się na temat człowieka w nurtach filozofii analityczno-naturalistycznych, można zauważyć, że nawiązują one do idei J. Locke’a, który oddzielił osobę od człowieka, łącząc ją z jakąś formą świadomości czy cechą rozumności (P. Singer i inni) ${ }^{6}$.

Można także wyróżnić etyczny paradygmat osoby, która jako podmiot czynów wolnych i odpowiedzialnych, staje się ,nosicielem wartości” (Wertträger). Spotykamy się z nim u Kanta. Wówczas mówimy, że człowiek nie tyle jest osobą, co staje się nią poprzez urzeczywistnianie wartości.

Wreszcie spotykamy paradygmat substancji, a więc bytu, który jest podmiotem (a nie przedmiotem) i wyróżnia się dynamizmem różnorodnych działań nakierowanych na realizację ostatecznego celu, jakim jest jego dobro. Rozumienie człowieka jako osoby otwiera szerokie pole jego formacji tak wdziedzinie rozwoju poznawczego, jak i moralnego oraz twórczego, co stanowi nowe wyzwanie dla budowanych współcześnie adekwatnych teorii wychowania. Substancjalna koncepcja osoby została wprowadzona do filozofii wraz z Boecjusza definicją człowieka jako rationalis naturae individua substantia (łac.). Definicja ta łączy w sobie podejście antropologiczno-metafizyczne, do którego nawiązuje pojęcie substancji rozumianej jako podmiot oraz pojęcie natury rozumnej; ponadto w punkcie wyjścia odwołuje się do doświadczenia.

Do tej definicji w średniowieczu nawiąże św. Tomasz z Akwinu, a w czasach współczesnych - twórcy Filozoficznej Szkoły Lubelskiej, w sposób szczególny Mieczysław A. Krąpiec i Karol Wojtyła.

\section{Człowiek jako osoba a adekwatna teoria wychowania}

\subsection{Podmiotowość i jedność osoby}

Adekwatny obraz człowieka, do którego nawiązują twórcy Filozoficznej Szkoły Lubelskiej, ma swe korzenie w antropologii Arystotelesa oraz św. Tomasza z Akwinu i może być podstawą formowania właściwej teorii wychowania.

\footnotetext{
${ }^{6}$ Zob. szerzej Grzegorz Hołub, „Naturalizm a początek życia osoby”, w: Wokół genezy człowieka, red. P. S. Mazur (Kraków: WAM 2013), 91-112.
} 
Kim jest człowiek jako osoba? Osoba jest przede wszystkim niepodzielnym w sobie (na duszę i ciało) podmiotem - głosi pierwsza zasada metafizyki osoby. Człowiek doświadcza tej niepodzielności i podmiotowości, co odnotowuje św. Tomasz słowami: [...] experitur enim unusquisque seipsum esse [...] qui percipit se et ingelligere et sentire [...] (experitur enim homo se esse idem quid intelligit et sentit). ${ }^{7}$ A zatem człowiek doświadcza siebie jako kogoś jednego, kto istnieje, odbiera wrażenia zmysłowe (odczuwa), poznaje umysłowo (myśli), wygłasza sądy, podejmuje wolne decyzje. Wszystko jest dziełem jednego i tego samego podmiotu, który jest rozumny i wolny.

Druga zasada metafizyki człowieka głosi, że człowiek jest istotą złożoną (łac. compositum) z ciała i duszy; wprawdzie bytuje w świecie natury (przyrody), ale jednak nie jest jej tworem ${ }^{8}$. Człowiek jako osoba jest w świecie bytów istotą wyjątkową, niesprowadzalną do żadnych innych istot! Dochodzimy do tego, analizując jego działanie. Źródłem specyficznego dla człowieka działania (poznania, wolności, miłości) nie może być podmiot (substancja), który jest czystym wytworem przyrody. Z tej racji należy koniecznie poszukiwać odpowiedniego źródła (podmiotu) dla tego typu działań, w myśl zasady agere sequitur esse (łac.: sposób działanie jest następstwem określonego sposobu istnienia). Zatem, skoro działanie ludzkie przekracza działanie natury, to i podmiot istnienia ludzkiego nie może być tworem natury.

Wszystko to stanowiło dla św. Tomasza postawę odkrycia duszy jako pierwszego aktu istnienia człowieka i podmiotu ludzkich działań. Skoro zatem źródła istnienia duszy (a zatem i człowieka) nie odnajdujemy w świecie natury, trzeba go poszukiwać poza nim. W ten sposób doszedł św. Tomasz do koncepcji duszy bezpośrednio stwarzanej przez Stwórcę. Dusza jest w pierwszym rzędzie aktem istnienia człowieka jako takiego. Dusza, będąc formą substancjalną bytu, jest indywidualna (a nie ogólna), gdyż jest aktem istnienia, a ten zawsze jest jednostkowy 9 .

Skoro dusza jest pierwszym aktem istnienia ciała ludzkiego, musi istnieć przed nim i być wobec niego suwerenna. Zatem ani ciało, ani układ części ciała nie może być jej źródłem. Jedynym źródłem tak pojętej duszy ludzkiej, a zatem i człowieka jako człowieka, jest Stwórca. „Człowiek rodzi człowieka i Bóg” (łac. Homo generat hominem et Deus), rodzice zaś uczestniczą w prokreacji (współstwarzaniu) -

\footnotetext{
${ }^{7}$ S. Thomae Aquinatis, Summa theologiae, cura et studio P. Caramello, vol. 1, (Taurini: Marietti 1963), I, q. 76 , a. 1 , resp.

8 Według bowiem Arystotelesa człowiek „powstał z natury i podług natury” [phýsei te kai katá physin gégone]), Arystoteles, Zachęta do filozofii, przekł. K. Leśniak (Warszawa: PWN 1988), frg. 16.

9 Dusza jest tym - wyjaśnia myśl Akwinaty Étienne Gilson - co „stanowi w rzeczy samej jej esse lub byt w znaczeniu essentia, quidditas, natura. Rozważmy jednakże bliżej tak określoną istotę. Cóż ona czyni? Powiedzieliśmy, że dokonuje różnych czynności życiowych, takich jak wegetacja, wzrost itp. Są to jej akty wtórne. Aby odnaleźć ich źródło, trzeba ponad tym, co dusza c z y n i - dosięgnąć tego, czym ona j e s t to znaczy dojść do jej aktu pierwszego. Stwierdzamy wówczas, że dusza jest życiem, i że ponieważ jest to akt jej istoty, jest to więc jej byt. Esse duszy jest tym właśnie w najgłębszym znaczeniu: esse rei est actus essentiae", Étienne Gilson, Byt i istota, przekt. P. Lublin, J. Nowak, (Warszawa: Pax 1963), 80.
} 
głosi kolejna zasada antropologii, wskazując równocześnie na źródło wyjątkowości człowieka i świętości jego życia.

Tomasz z Akwinu wyjaśniał, że „dusza owo istnienie przez które samobytuje, udziela cielesnej materii, z której to i duszy rozumnej (intelektualnej) staje się (czymś) jednym i to do tego stopnia, że to samo istnienie, które jest istnieniem (powstałego) całego złożenia, jest także istnieniem samej duszy. A to nie ma miejsca pośród innych form, które nie są samobytujące. Dlatego to właśnie ludzka dusza pozostaje w swym istnieniu po zniszczeniu ciała. Ale inne formy nie [trwają nadal]"10. Dusza ludzka, choć istnieje „sama w sobie” jako we własnym i odpowiednim dla siebie podmiocie, jest jednak przyporządkowana do ciała, wraz z którym stanowi byt ludzki, ludzką osobę. Dzięki temu może tworzyć sobie ciało i udzielać mu ludzkiego istnienia ${ }^{11}$. W ten sposób dochodzi w człowieku do zsyntetyzowania materii i ducha, który - działając jako jeden podmiot - ujawnia w swoim działaniu transcendencję nad materią, przyporządkowując ją transcendentnemu celowi wpisanemu w tę naturę ${ }^{12}$.

\subsection{Prawda o ludzkiej osobie}

W metafizycznych, a zarazem realistycznych dociekaniach nad osobą, od wieków średnich do czasów współczesnych, możemy wyróżnić jakby trzy etapy odsłaniania prawdy o osobie ludzkiej.

a) Pierwszy etap odsłaniania adekwatnej wizji wiążemy ze św. Tomaszem z Akwinu. Charakterystycznym rysem Tomaszowej metafizyki człowieka jest to, że ukazuje w niej osobę ludzką nie tyle w tym, „kim i czym jest”, a więc statycznie, lecz w tym „jak działa i co powinna czynić”, by w pełni zrealizować swe człowieczeństwo,

${ }^{10},[. .$.$] anima illud esse in quo ipsa subsistit, communicat materiae corporali, ex qua et anima intellectiva$ fit unum, ita quod illud esse, quod est totius compositi, est etiam ipsius animae. Quod non accidit in aliis formis, quae non sunt subsistentes. Et propter hoc anima humana remanet in suo esse, destructo corpore, non autem aliae formae" (S. Thomae Aquinatis, Summa theologiae, dz. cyt. I, q. 76, a. 1, ad 5, resp.)

${ }^{11}$ W przeciwnym wypadku - jak wyjaśnia Krapiec - „owo udzielanie istnienia byłoby bezcelowe. Zresztą nie doświadczamy żadnego ludzkiego działania, które nie dokonywałoby się bez pośrednictwa ludzkiego ciała. Wszelkie ludzkie działania poznawcze, pożądawcze, motoryczne dokonują się poprzez ludzkie ciało i w lączności z ludzkim ciałem, które jest nieustannie organizowane przez duszę [...]. Ale to nie znaczy, że struktura niektórych ludzkich czynności nie jest niematerialna. I to ma miejsce w działaniu duchowych władz człowieka, jakimi są rozum i wola. Władze te bezpośrednio wyłaniają się z duszy jako tzw. możności czynne, których akty, jakimi są: intelektualne poznanie w postaci pojęć, sądów, rozumowania oraz akty woli w postaci miłości w jej różnych wyrazach, są właśnie niematerialne. Władze te, rozum i wola, nie posiadają żadnego organu. Mózg bowiem stanowi system organów dla poznania zmysłowego, natomiast akty poznania intelektualnego i akty woli nie wypływają z żadnego organu, aczkolwiek nie dokonują się bez powiązania z działaniem zmysłowych aktów poznania i pożądania (uczucia). Funkcjonowanie aktów duchowych posiada swoje zaplecze w działaniu zmysłów". Mieczysław A. Krąpiec, Arystotelesowska koncepcja substancji, Dzieła VI (Lublin: RW KUL 2000), 134.

${ }^{12} \mathrm{Z}$ tej racji cały człowiek, jako byt przygodny, rozpoznaje się jako istota otwarta na Najwyższe Dobro, którego ostateczną racją istnienia i działania jest Absolut. Uświadamia nam to wyznanie św. Augustyna z Hippony: „Niespokojne jest serce człowieka, dopóki nie spocznie w Bogu”. Dążenie to wyznacza ostateczną perspektywę ludzkiego życia i postępowania, cel i kres wszelkiego dążenia. 
a więc w aspekcie sprawnościowym i celowościowym („dobro należy czynić!”). Z tej racji Tomasz poświęca wiele uwagi teorii cnót jako adekwatnych narzędzi wychowania i formacji osoby ludzkiej, ukazując jej życie w kontekście usprawnionego (przez cnoty) działania. Sposób bowiem doskonałościowego działania (życia według cnót) najpełniej odsłania naturę bytu osobowego, ukazując dziedzinę dobra osobowego jako ostateczny cel i motyw tego działania ${ }^{13}$. Kształcenie charakteru poprzez zdobywanie usprawnień tak w dziedzinie moralnej, jak i intelektualnej, twórczej oraz społecznej, to wyzwanie, jakie płynie z Tomaszowej antropologii przy budowaniu adekwatnej teorii wychowania.

b) Drugim etapem odsłaniania prawdy o osobie, z którym spotykamy się wśród twórców Filozoficznej Szkoły Lubelskiej, jest odkrycie i ukazanie faktu transcendencji osoby nad przyrodą (naturą) i społeczeństwem. Wydobycie tego aspektu jest bardzo ważnie szczególnie dla pedagogiki i psychologii (a także dla polityki oraz ekonomii), a zawdzięczamy to Mieczysławowi A. Krąpcowi.

Krąpiec nawiązuje do słownikowego znaczenia słowa „osoba” (łac. persona), wyprowadzanego z greckiego prósopon oznaczającego maskę, którą posługiwano się w starożytnym teatrze. Maska zakładana przez aktora w zależności od kształtu określała, czy mamy do czynienia z tragedią, czy z komedią; była także swoistą tubą, aby ułatwić rozumienie treści sztuki, która jednak była rozpoznawana dopiero po słowach i gestach aktora. Takie rozumienie naprowadza nas na znaczenie terminu „osoba”.

Doświadczamy bezpośrednio siebie jako osoby (podmiotu) w doświadczaniu własnego ,ja” (jaźni osoby) i w doświadczeniu działania osobowego. To doświadczenie jest jakby multiplikowane przez doświadczenie pośrednie, które dokonuje się w tym, co „moje”. W ten sposób owo doświadczenie „ja-osoby” dopełnione jest doświadczeniem moich aktów poznawania, wolności (decyzji), miłości i religijności, co stanowi poszerzone - w stosunku do św. Tomasza z Akwinu - przez Krąpca pole ludzkiego doświadczenia. W tym wewnętrznym doświadczeniu odkrywamy swoją własną podmiotowość, na którą wskazują akty: poznawania, wolności, miłości i religijności.

„Owo «ja» - wyjaśnia Krąpiec - jest mi dane od strony faktu-aktu istnienia, a nie od strony treści tegoż «ja». Znaczy to, że mam doświadczenie: doświadczam, że ja istnieję, że ja żyję, ale nie znam treści «ja», nie znam mojej konkretnej natury. Ona jest mi dana jedynie od strony podmiotowości moich aktów i od strony tożsamości wewnętrznej. Jako podmiot bowiem wyłaniam - i to czuję - moje czynności duchowe w postaci np. poznania intelektualnego i zarazem to samo «ja» wyłania czynności zmysłowe, i jest doświadczane jako ten sam podmiot obu tych heterogenicznych aktów.

\footnotetext{
${ }^{13}$ Ten aspekt antropologii Tomasza z Akwinu stanowił element inspiracji dla Jacka Woronieckiego przy pisaniu Katolickiej etyki wychowawczej. Woroniecki, na bazie Tomaszowej aretologii, zwrócił uwagę, na potrzebę powiązania na nowo pedagogiki z etyką, a etyki z aretologią.
} 
Zatem «ja» jest immanentne w tych heterogenicznych aktach «moich», albowiem to ja jestem tychże aktów podmiotem (experitur enim unusquisque se esse idem qui intelligit et sentit). Jestem bowiem podmiotem tym samym dla mych aktów intelektualnopoznawczych, jak i dla aktów zmysłowopoznawczych; doświadczam, że to właśnie «ja» myślę, «ja» rozumiem i tak samo «ja» widzę, «ja» odczuwam ból [...].

Zarazem jednak doświadczam i tego, że żaden $\mathrm{z}$ mych aktów, czy to duchowych, zmysłowych, czy biologicznych - chociaż bywają to akty niezwykle intensywne - nie wyczerpał inie zagarnął całej treści «ja», albowiem ciągle transcenduję siebie, czyli transcenduję wszystkie moje poszczególne akty oraz wszystkie akty razem wzięte [...].

Jest więc nam dane wewnętrzne doświadczenie własnego «ja» jako podmiotu dostrzeganych «moich» działań. Podmiot (substantia) jest nieustannie doświadczany jako ten sam we wszystkich swoich działaniach, zarówno biologicznych, jak i psychicznych, zmysłowych, jak wreszcie duchowych - poznawczych, wolitywnych lub pożądawczych" 14 .

W przypadku człowieka spotykamy się z tą wyjątkową sytuacją, że może to być „ogląd bezpośredni” dokonywany zarówno „od wewnątrz”, jak i „od zewnątrz”. Człowiek bowiem dany jest sobie bezpośrednio w aktach świadomego istnienia. Doświadcza i widzi siebie jako „ja” spełniające akty „moje”. Analiza tego doświadczenia stanowi podstawę odkrywania struktury bytowej człowieka i poznania specyfiki jego działania.

Aby ujawnić naturę i specyfikę istnienia bytu osobowego, należy wydobyć wszystkie te elementy, które stanowią o jego charakterze. Możemy to uczynić, według Krąpca, na dwa sposoby:

1. Metodą wykluczania przypadkowych właściwości, które nie wskazują na specyfikę bytu osobowego, by dotrzeć do tych, które determinują bytowanie podmiotu (substancji) na sposób osoby; na przykład analizujemy, czy forma albo jakaś inna szczególna przypadłość determinuje bytowanie podmiotu (substancji) jako osoby. Forma jako taka nie może tego czynić, gdyż wówczas osoba nie różniłaby się od innych bytów. Nie może to być także jakaś właściwość przypadłościowa, gdyż nie stanowiłaby o doskonałości i specyfice substancji jako osoby. Może być tym tylko to, co determinuje sposób istnienia osoby, czyli specyficzny akt, którym jest rozumna dusza.

2. Metoda pozytywna polega na analizie działania człowieka jako człowieka i wyodrębnieniu takich działań, które stanowią o jego doskonałości i odrębności. Analizy te ujawniają także podmiotowość, niepodzielność, indywidualność i racjonalność osoby. Wyodrębnienie tych cech jest efektem filozoficznej analizy aktów mojego działania. Wśród odkrytych cech jako najbardziej podstawowe wyróżniono: zdolność do poznania, do wolności, miłości, religijności, a także godność, podmiotowość wobec prawa i zupełność. Właściwości te ukazują transcendencję człowieka jako osoby w stosunku do świata przyrody i społeczeństwa; w ten sposób odsłaniają specyfikę bytu osobowego. Przyjrzyjmy się bliżej tym właściwościom ujawniającym sposób jego istnienia.

\footnotetext{
${ }^{14}$ Krąpiec, Arystotelesowska koncepcja substancji, 130-131.
} 
Zdolność do poznania. Działalność poznawczą człowieka odkrywamy i wyróżniamy na tle jego zdolności do abstrakcyjnego myślenia, wypowiadania sądów, przeprowadzania rozumowań i w perspektywie całej dziedziny kultury, która jest znakiem poznawczej działalności ludzi. To właśnie w niej człowiek spełnia się jako byt rozumny, a także ujawnia swoją transcendencję wobec świata materii i całej przyrody. W wytworach sztuki oraz kultury, a więc w swej działalności twórczej, pokazuje, że potrafi materię poddawać prawom umysłu i ducha, nadając jej różnorodne formy oraz funkcje.

Zdolność do miłości. Jest ona czymś więcej niż tylko odkrywanym pożądaniem i stałą inklinacją do dobra. Człowiek dba nie tylko o własne dobro (co byłoby wyrazem naturalnej inklinacji), ale także potrafi poświęcać się na rzecz dobra drugiej osoby, stąd miłość kobiety do mężczyzny, matki do dziecka, jednego człowieka do drugiego mierzona jest zdolnością do poświęcenia własnego życia dla innych, podejmowania aktów solidarności z drugimi.

Zd olność d o wo ln o ści. Akt wolności wyraża się w sądzie praktycznym, czyli decyzji, którą podejmujemy dla zrealizowania jakiegoś dobra. Ponadto akt wolności wyraża się w tym, że to my sami musimy siebie determinować do działania: możemy je skierować przeciw inklinacjom natury, działać przeciw sobie, możemy także, wybierając właściwe dla swej natury dobra, stawiać sobie właściwe cele.

Zdolność do religijności. Tylko człowiek jako byt racjonalny odczytuje istnienie Boga jako ostatecznej racji swego życia i istnienia. Tylko człowiek przez akty modlitwy, kult i obrzędy zwraca się do Boga i w ten sposób wyraża Jego afirmację, równocześnie ukazując swą transcendencję.

Te cztery właściwości bytu osobowego odsłaniają transcendencję bytu ludzkiego w stosunku do świata przyrody. I choć człowiek jest jej częścią i żyje w świecie przyrody, to równocześnie ten świat przekracza, ukazując w ten sposób, że jest osobą, czyli świadomym, niepodzielonym podmiotem, zdolnym do autonomicznego życia i działania, a nie „osobnikiem”. Ponadto waktach tych i poprzez nie człowiek kształtuje swą osobowość, nie jest do końca zdeterminowany prawami przyrody i biologii. Siłą ducha może podbijać (i faktycznie podbija) świat przyrody, podporządkowując go prawom ducha (świadczy o tym kultura); także sam swoje fizyczne ograniczenia oddaje pod władzę praw ducha (świadczą o tym przykłady świętych, bohaterów, sportowców i innych). Dla formowania teorii pedagogicznych czy psychologicznych odkrycie faktu transcendencji człowieka na tym, co w nim i poza nim należy do świata natury, jest niesłychanie ważne, otwiera bowiem szerokie pole widzenia środków, z których może korzystać pedagog czy psycholog w procesie wychowania.

Odkrywając kolejne cechy osobowe charakterystyczne dla człowieka jako istoty społecznej, odkrywamy jego transcendencję w stosunku do społeczności i różnorodnych instytucji.

G o d n o ść . Odkrycie godności ludzkiej na terenie antropologii klasycznej wyrasta z odpoznania bytu ludzkiego jako najwyżej stojącego w hierarchii bytów (ze 
względu na wcześniej odkryte właściwości: zdolność do poznania, wolności, miłości, religijności). Wynika to stąd, że byt ludzki jako taki nie może być traktowany jako środek dla państwa, społeczności, instytucji czy polityki. On może być, jest - celem i tylko celem ${ }^{15}$. Ta prawda o osobie ludzkiej, która ukazuje człowieka, jako cel wszelkich działań, w kontekście życia społecznego jest prawdą, która może przeciwstawiać się wszelkim jawnym i ukrytym alienacjom człowieka. Co więcej, prawda o godności ludzkiej jest „narzędziem” demaskowania i rozpoznawania owej alienacji w tworzonych teoriach pedagogicznych, psychologicznych, etycznych czy politycznych.

Podmi otowość wobec prawa. Cecha ta ujawnia, że wszelkie tworzone prawa muszą mieć na uwadze dobro człowieka jako człowieka, to znaczy nie mogą być tworzone przeciw człowiekowi (jak na przykład prawo do kary śmierci, aborcji, niewolnictwa itp.). Mogą natomiast istnieć prawa wymierzone przeciw człowiekowi (jako na przykład złodziejowi czy zabójcy). Wszelkie prawa winny mieć na celu (bezpośrednio lub pośrednio) ochronę człowieka jako człowieka; ich celem jest ułatwić czynienie dobra, a utrudnić - zła. Zatem prawo, którego człowiek jest podmiotem i przedmiotem, pełni nie tylko funkcje restrykcyjną, ale i wychowawczą.

$\mathrm{Z}$ u p e ł n o ś ć . Cecha zupełności, która przysługuje osobie, wskazuje, że choć człowiek jest istotą społeczną, żyje w społeczności i rozwija się dzięki niej, to jednak $\mathrm{w}$ istocie swej jest bytem zupełnym. Znaczy to, że ani społeczeństwo, ani inne czynniki zewnętrzne nie dodają nic do jego natury i człowieczeństwa; wszystko jest potencjalnie złożone w nim samym. Stąd ani instytucje, ani praca, ani kolektyw nie są czynnikami antropotwórczymi, człowiek bowiem zawsze jest człowiekiem i to nie dzięki pracy czy kolektywowi (lub czemuś innemu), co czyniłoby go dopiero człowiekiem $^{16}$. Cechy te ukazujące transcendencję bytu ludzkiego w odniesieniu do społeczeństwa i instytucji uwrażliwiają twórców teorii pedagogicznych, psychologicznych, etycznych czy politycznych na to, by byli świadomi, iż wszelkie społeczności oraz instytucje, poczynając od rodziny, po szkołę, Kościół, naród, a na państwie kończąc, mają funkcję pomocniczą i tylko pomocniczą; wyłącznie w ten sposób winna być ona uwzględniana.

c) Trzecim etapem odsłaniania adekwatnej prawdy o osobie ludzkiej jest wskazanie na specyfikę działania ludzkiego. Człowiek jako osoba rozpoznawany jest w czynie i poprzez czyn. Także czyn ludzki, ludzkie działanie, jest miejscem, w którym człowiek „doświadcza samego siebie”. Na to właśnie miejsce „doświadczenia

15 We współczesnej kulturze pojęcie godności może występować w kontekście: 1) religii - wówczas godność ludzka wynika z faktu, że jesteśmy dziećmi Bożymi; 2) socjologii - tym pojęciem operuje na przykład Karta Praw Człowieka. Godność ludzką określają warunki życia (tzw. minimum socjalne); 3) filozofii - pojęcie godności wynika z rozpoznania natury bytu ludzkiego i jego odrębności w stosunku do świata przyrody.

${ }^{16}$ Doświadczenie bycia podmiotem zostało wydobyte przez ukazanie specyfiki ludzkiego działania, które odsłania się w aktach decyzyjnych: samoposiadania, samostanowienia, samopanowania, co zawdzięczamy K. Wojtyle. Zagadnienie to wymaga jednak oddzielnego omówienia. 
człowieka" zwrócił uwagę Karol Wojtyła ${ }^{17}$. Człowiek doświadcza siebie inaczej niż doświadcza innych bytów: nie jako przedmiot, ale jako podmiot, a więc jako „źródło zdeterminowanego działania”. Doświadcza swojej podmiotowości waktach podmiotowania. Doświadcza siebie, jako tego, kto działa, czyli jako podmiot, który wydobywa z siebie określone działania. Człowiek jest tym, „co czyni”; actus humans jest miejscem odkrywania prawdy o człowieku.

O ile Krąpiec w punkcie wyjścia swoich analiz akcentuje aspekt transcendencji w kontekście doświadczenia bycia osobą jako najbardziej pierwotnego doświadczenia „ja” i „tego, co moje”, to Wojtyła akcentuje ,ja działam” (osoba i czyn). Celem tego działania jest owszem zdobycie usprawnien (cnót), by odkryć i na nowo doświadczyć własnego: samoposiadania, samostanowienia, samopanowania. Główną zaś zasadą działania antropologii Karola Wojtyły jest miłość i odpowiedzialność. Wraz z odkryciem tego aspektu życia osoby odsłania się przed twórcami teorii pedagogicznych czy psychologicznych nowe pole wyzwań i inspiracji.

Należy jednak na zakończenie podkreślić, że w ramach poszukiwania antropologiczno-metafizycznych podstaw dla adekwatnej teorii wychowania w ujęciu twórców Filozoficznej Szkoły Lubelskiej otrzymujemy bardzo bogaty i zróżnicowany obraz człowieka - osoby, który wyróżnia się wyjątkowością i niepowtarzalnością. Jest to więc wizja integralna, całościowa i spójna. Całościowość i integralność tę wyznacza rozumienie człowieka jako istoty cielesno-duchowej, compositum ciała i duszy, gdzie czynnik cielesny, uczuciowy i duchowy przenikają się nawzajem, a nie są sobie przeciwstawiane. Jest to też wizja realistyczna i neutralna, gdyż punktem wyjścia jest doświadczenie faktu ludzkiego (od wewnątrz i od zewnątrz) - i na bazie tego doświadczenia budowana jest teoretyczna wizja człowieka. Wypracowany obraz człowieka jako osoby (jednostkowego, rozumnego, zdeterminowanego co do natury i działania podmiotu) w ramach realistycznej filozofii Lubelskiej Szkoły Filozoficznej jest dziś ważną propozycją nie do przecenienia, by takie rozumienie człowieka przyjąć jako zasadę budowania adekwatnej teorii wychowania. Teoria wychowania powinna bowiem być wypadkową rozumienia człowieka i jego ostatecznego celu życia.

Zakończmy te rozważania zachętą kierowaną przez Arystotelesa do tych, którzy życie swe poświęcają badaniom teoretycznym, a więc i pedagogom. „To, że teoretyczne myślenie - wyjaśnia Arystoteles - daje ludziom największe korzyści, można dostrzec łatwo w skutkach praktycznych. Bo tak, jak rozumni lekarze i liczni znawcy ćwiczeń [...] muszą mieć ogólną wiedzę o przyrodzie, tak też dobrzy prawodawcy [nauczyciele, tworzący teorie i inni - dop. tu i dalej A.M.] muszą mieć

\footnotetext{
${ }^{17}$ Zob. szerzej Zofia Zdybicka, Jan Paweł II - filozof i mistyk (Lublin: PTTA 2009); tejże, „Wojtyła Karol”, w: Powszechna encyklopedia filozofii, t. 9, red. nacz. Andrzej Maryniarczyk (Lublin: PTTA 2008), 815-822; Rocco Buttiglione, Myśl Karola Wojtyły, przeł. J. Merecki SDS (Lublin: TN KUL 1996); Jan Galarowicz, Czlowiek jest osobą: podstawy antropologii filozoficznej Karola Wojtyly (Kęty: ANTYK 2000); Karol Wojtyła, „Osobowa struktura samostanowienia”, w: Osoba i czyn oraz inne studia antropologiczne (Lublin: TN KUL 1994), 430.
} 
ogólną wiedzę o przyrodzie [o świecie i człowieku], i to w stopniu o wiele większym niż ci pierwsi. Tamci bowiem są tylko twórcami doskonałości ciała, ci drudzy natomiast [pedagodzy, etycy, politycy] interesują się doskonałością duszy i chcą uczyć o dobrym i złym stanie państwa [życia, postępowania], i z tego powodu potrzebują jeszcze więcej filozofii”"18.

Z tej to właśnie racji zachęca Arystoteles: „nie powinniśmy stronić od filozofii, jeżeli ona jest, jak sądzimy, posiadaniem i uprawianiem mądrości, a mądrość jest najlepszym ze wszystkich dóbr; i jeżeli w pogoni za korzyścią materialną narażamy się na niebezpieczeństwo płynąc aż do Słupów Heraklesa, to tym bardziej nie powinniśmy lękać się trudu i kosztów w dążeniu do mądrości”"

Streszczenie: Wyrażenie zawarte w tytule artykułu „metafizyczno-antropologiczne podstawy" zapowiada nie tyle odwołanie się do jakiegoś systemu filozoficznego, który stałby u podstaw teorii wychowania, co pewną postawę badawczą, którą wyróżnia realizm. Tego typu postawa sprowadza się do „sztuki czytania” realnie istniejących bytów: osób i rzeczy oraz odkrywania w nich koniecznych przyczyn istnienia i działania oraz powszechnych właściwości. W artykule wskazano, że poprawne odczytanie prawdy o człowieku, o tym, kim jest, jakie jest ostateczne źródło jego istnienia orazjaki jest ostateczny cel jego życia, stanowi nieodzowny warunek formowania adekwatnej teorii wychowania. W ramach poznania filozoficznego odkrywamy, że człowiek jest osobą, to znaczy jednostkowym podmiotem, będącym źródłem wolnego i rozumnego działania, posiadającym określoną naturę oraz jest istotą żyjącą w perspektywie Absolutu (Boga), na co wskazuje odczytanie ostatecznej prawdy o istnieniu świata i człowieka. Tego typu wiedzy dostarcza pedagogice metafizyka i antropologia filozoficzna, którą sformułowano i rozwija się nadal w ramach Lubelskiej Szkoły Filozoficznej.

Słowa kluczowe: antropologia filozoficzna, metafizyka, osoba, teoria wychowania, pedagogika

\section{Bibliografia}

Arystoteles, O niebie, przel. P. Siwek, Dzieła wszystkie, t. 2, Warszawa: PWN, 1990.

Arystoteles, Zachęta do filozofii, przel. K. Leśniak, Warszawa: PWN, 1988.

Buttiglione, Rocca, Myśl Karola Wojtyły, przeł. J. Merecki SDS, Lublin: TN KUL, 1996.

Gilson, Étienne, Byt i istota, przeł. P. Lublin, J. Nowak, Warszawa: Pax, 1963.

Hołub, Grzegorz, „Naturalizm a początek życia osoby”, w: Wokót genezy czlowieka, red. P.S. Mazur. 91-112. Kraków: WAM, 2013.

Galarowicz, Jan, Czlowiekjest osobq: podstawy antropologïfilozoficznej Karola Wojtyly, Kęty: ANTYK, 2000. Wojtyła, Karol. „Osobowa struktura samostanowienia”, w: Osoba i czyn oraz inne studia antropologiczne, Lublin: TN KUL, 1994.

\footnotetext{
${ }^{18}$ Arystoteles, Zachęta do filozofii, przekł. K. Leśniak (Warszawa: PWN 1988), frg. 46.

19 Tamże, frg. 53.
} 
Krąpiec Mieczysław A. „Człowiek”, w: Powszechna encyklopedia filozofii, t. 2, red. nacz. Andrzej Maryniarczyk, 359-386. Lublin: PTTA, 2001.

Krąpiec, Mieczysław A. Arystotelesowska koncepcja substancji, Dzieła VI, Lublin: RW KUL, 200.

Maryniarczyk Andrzej, Mieczysław A. Krąpiec, „Lubelska Szkoła Filozoficzna”, w: Powszechna encyklopedia filozofii, t. 6, red. nacz. Andrzej Maryniarczyk, 532-550. Lublin: PTTA, 2005.

S. Thomae Aquinatis, Summa theologiae, cura et studio P. Caramello, vol. 1. Taurini: Marietti, 1963.

Zdybicka, Zofia J. Jan Paweł II - filozof i mistyk, Lublin: PTTA, 2009.

Zdybicka, Zofia J., „Wojtyła Karol”, w: Powszechna encyklopedia filozofii, t. 9, red. nacz. Andrzej Maryniarczyk. 815-822. Lublin: PTTA, 2008. 